\title{
TOTAL ACID-BASE EQUILIBRIUM OF PLASMA IN HEALTH AND DISEASE
}

\author{
VII. Factors Causing Acidosis in Chronic Nephritis.
} A Preliminary Report

BY HAROLD A. BULGER, JOHN P. PETERS, ANNA J. EISENMAN AND CARTER LEE

(From the Department of Internal Medicine of Yale University and the Medical Service of the New Haven Hospital, Nerv Haven, Conn.)

(Received for publication August 6, 1925)

Throughout this paper the term acidosis is used in the sense in which it was employed by Van Slyke and Cullen (1) to define "a condition in which the bicarbonate of the blood is reduced below the normal level." They have pointed out that the bicarbonate represents the excess of base which is left after all of the non-volatile acids have been neutralized and that this is the base available for the immediate neutralization of any further increments of acids.

Acidosis is an almost constant feature of the later stages of chronic interstitial and arteriosclerotic nephritis. In a series of such cases the inorganic constituents of the serum have been determined in order to obtain some indication of the cause of the acidosis. Studies of other types of kidney insufficiency have not been included in this report.

\section{EXPERIMENTAL PROCEDURE}

In most cases arterial blood was obtained in the morning before breakfast and the plasma or serum separated at once without exposure to air. In a few cases plasma obtained from venous blood collected without stasis was used. In a few other cases venous blood was saturated at $38^{\circ} \mathrm{C}$. with $\mathrm{CO}_{2}$ at $40 \mathrm{~mm}$. pressure and the plasma then obtained. The determinations in earlier studies were made on plasma from oxalated blood while later ones were on serum. Blood in these later studies was defibrinated by continuously inverting and reinverting the sampling tube containing the blood and a small amount of mercury. With care serum can be obtained in this way without hemolysis. Further details of the technique used in handling blood have been described in previous articles (2). 
Total base was determined by Cullen and Robinson's ${ }^{1}$ adaptation of Fiske's urine method. Chloride was determined by Austin and Van Slyke's (3) method in earlier studies and Van Slyke's method (4) in later studies, $\mathrm{CO}_{2}$ by Van Slyke and :Stadie's method (5) and phosphate by Briggs' (6) or Benedict and Theis' (7) modification of Bell and Doisy's method. The protein was calculated from the nitrogen determination by the ordinary Kjeldahl method corrected for the non-protein nitrogen. The non-protein nitrogen as determined on whole blood was used for this correction instead of actual plasma figures. The error incurred by this procedure is slight.

Base combined with protein at any given $\mathrm{pH}$ was calculated by the formula devised by Van Slyke, Wu and McLean (8) from experimental data. In calculating the base combined with phosphate it was assumed that in each sample of plasma or serum mono-basic and di-basic phosphate were present in the ratio 1:4. Theoretically this ratio varies somewhat according to the $\mathrm{pH}$. The error involved in neglecting these variations is slight. In an extreme case with $15 \mathrm{mg}$. of inorganic phosphate per $100 \mathrm{cc}$. of serum and a $\mathrm{pH}$ of 7.00 the base combined with phosphate calculated by this method would be one millimol too high. In the cases where $\mathrm{pH}$ was not determined and the $\mathrm{CO}_{2}$ tension was not known, a pH of 7.35 was arbitrarily assumed in calculating the dissolved $\mathrm{CO}_{2}$ and the base combined with protein.

\section{EXPERIMENTAL RESULTS}

Besides the reduction of bicarbonate one frequently finds a reduction of plasma chloride. The frequency and degree of this reduction is illustrated in table 1 . (The values throughout these tables are expressed in $\mathrm{mM}$. of base-combining capacity.) ' In normal subjects the chloride fell between 100 and $110 \mathrm{mM}$.; in 77 determinations in nephritis much greater variations were encountered. In over onehalf of the determinations chloride was distinctly below normal, in 5 above normal. The magnitude of the chloride deficit frequently exceeded the total capacity of bicarbonate.

Table 2 shows the variation in the base bound by bicarbonate, chloride and protein combined, the 3 most significant acids of normal plasm. Normal subjects varied between 135 and $145 \mathrm{mM}$. Low values were found in 66 out of 77 determinations on cases of nephritis and in more than one-half the reduction was considerable.

Retention of phosphate has commonly been considered an important factor in the production of acidosis in chronic nephritis. In table 3 are recorded 46 determinations which also included the base bound with phosphate. High phosphate was found in most

\footnotetext{
${ }^{1}$ Personal communication.
} 
of these cases but the phosphate increases were quite insufficient to bring the sums of the acids to normal. In 35 out of 46 determinations base combined with bicarbonate, chloride, protein and phosphate was definitely reduced.

Total base as well as the acids already enumerated have been determined 25 times in nephritis. Serum being practically neutral, the

TABLE 1

Chloride variation in chronic nephritis

\begin{tabular}{|c|c|c|c|}
\hline & $\begin{array}{c}\text { NUMBER OF } \\
\text { DETERMINATIONS }\end{array}$ & NUMBER OF CASES & $\begin{array}{l}\text { LIMITS OF } \\
\text { VARIATION }\end{array}$ \\
\hline & & & $m M$. \\
\hline 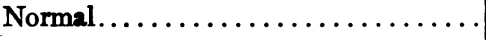 & & & $100.0-110.0$ \\
\hline Nephritis, total................ & 77 & 28 & $67.3-127.1$ \\
\hline Nephritis..................... & 8 & 5 & $67.3-80.0$ \\
\hline Nephritis.................... & 20 & 9 & $80.0-90.0$ \\
\hline Nephritis...................... & 18 & 11 & $90.0-100.0$ \\
\hline Nephritis.............. & 26 & 13 & $100.0-110.0$ \\
\hline Nephritis ................ & 5 & 4 & $110.0-127.1$ \\
\hline
\end{tabular}

TABLE 2

Variation of base combined with bicarbonate, chloride and protcin

\begin{tabular}{|c|c|c|c|}
\hline & $\begin{array}{l}\text { NUMBER OP } \\
\text { DETERMINATIONS }\end{array}$ & NUMBER OF CASES & $\begin{array}{l}\text { LIMITS OF } \\
\text { VAR IATION }\end{array}$ \\
\hline Normal & & & $\stackrel{m M .}{ }$ \\
\hline 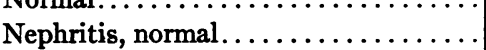 & 77 & 28 & $91.0-150.1$ \\
\hline Nephritis............... & 6 & 5 & $91.0-105.0$ \\
\hline Nephritis................... & 12 & 8 & $105.0-115.0$ \\
\hline Nephritis $\ldots \ldots \ldots \ldots \ldots \ldots \ldots \ldots$ & 23 & 11 & $115.0-125.0$ \\
\hline 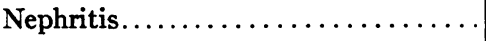 & 23 & 13 & $125.0-135.0$ \\
\hline Nephritis................ & 11 & 8 & $135.0-145.0$ \\
\hline Nephritis................... & 2 & 2 & $145.0-150.1$ \\
\hline
\end{tabular}

sum of the total acids must equal the base. Base may be considered a measure of the total electrolyte concentration. In normal subjects base has varied between 150 and $165 \mathrm{mM}$. In the 25 determinations on cases of nephritis it has been definitely reduced in $\mathbf{1 2}$ and above normal in three (table 4). A reduction of the total electrolyte level is therefore one factor in the mechanism producing acidosis and low chloride in nephritis. 
Gram (9) found the freezing point of sera from cases with uremia lower than normal, indicating to him an increase in osmotic pressure. Associated with this he found a decrease of chloride and electrical conductivity. He suggested that there was a decrease of electrolytes in the serum to compensate for the osmotic effect of the increase of nitrogen waste products. In this series no clear relationship can be established between the amount of base and the level of non-protein nitrogen.

The question arises to what extent other undetermined acids may have replaced bicarbonate and chloride from combination with base. This is indicated in table 5 which is a study of the difference between the total acids determined and the total base. This difference in

TABLE 3

Variation of base combined with bicarbonate, chloride, protein and phosphates

\begin{tabular}{|c|c|c|c|}
\hline & $\begin{array}{c}\text { NUMBER OF } \\
\text { DETERMINATIONS }\end{array}$ & NUMBER OF CASES & $\begin{array}{l}\text { LNMTrS OF } \\
\text { VARIATION }\end{array}$ \\
\hline Normal... & & & $\begin{array}{c}m M . \\
136.0-148.0\end{array}$ \\
\hline Nephritis, total.. & 46 & 16 & $100.7-152.6$ \\
\hline Nephritis........ & 3 & 1 & $100.0-115.0$ \\
\hline Nephritis $\ldots \ldots \ldots \ldots \ldots$ & 11 & 6 & $115.0-125.0$ \\
\hline Nephritis.. & 21 & 10 & $125.0-135.0$ \\
\hline Nephritis. . & 11 & 5 & $135.0-152.6$ \\
\hline
\end{tabular}

normal subjects has always been less than $20 \mathrm{mM}$. Out of 25 determinations in this type of nephritis it was greater than 20 in eighteen. In this we have an additional and important factor producing the low bicarbonate and chloride. If, as Denis (10) has suggested, high sulfate is of common occurrence among these cases, part of the augmented acid deficit presumably represents sulfate. This can hardly account for the total and one is forced to the conclusion that organic acids must also play a part.

It seems clear therefore that more than one factor is active in the mechanism producing acidosis in chronic nephritis. Retention of phosphate is almost invariably present in the later stages of disease. Increase in serum phosphate plays a significant rôle in reducing the base available for bicarbonate but in the majority of cases this is not 
the most important factor. The diminution of total base is frequently quite striking and in addition there is evidence of a marked increase in organic acids.

Marrack (11) has made a study of the inorganic constituents of sera from cases of chronic nephritis. He determined only the bicarbonate, chloride, phosphate and sodium but this was sufficient to indicate

TABLE 4

Variation of total base in chronic nephritis

\begin{tabular}{|c|c|c|c|}
\hline & $\begin{array}{c}\text { NUMBER OF } \\
\text { DETERMINATIONS }\end{array}$ & NUMBER OF CASES & $\begin{array}{l}\text { LIMITS OF } \\
\text { VARIATION }\end{array}$ \\
\hline 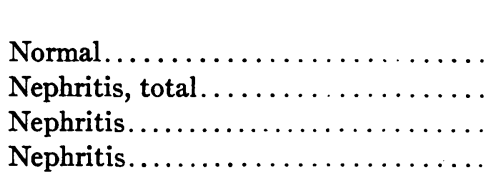 & $\begin{array}{r}25 \\
5 \\
7\end{array}$ & $\begin{array}{r}13 \\
2 \\
6\end{array}$ & $\begin{array}{c}m M . \\
150.0-165.0 \\
135.1-199.2 \\
135.1-14.5 .5 \\
145.0-150.0\end{array}$ \\
\hline 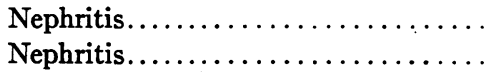 & $\begin{array}{r}10 \\
3\end{array}$ & $\begin{array}{l}6 \\
2\end{array}$ & $\begin{array}{l}150.0-165.0 \\
165.0-199.2\end{array}$ \\
\hline
\end{tabular}

T ABLE 5

Variation of undetermined acids in chronic nephritis

\begin{tabular}{|c|c|c|c|}
\hline & $\begin{array}{c}\text { NUMBER OF } \\
\text { DETERMINATIONS }\end{array}$ & NUMBER OF CASES & $\begin{array}{l}\text { LIMITS OF } \\
\text { VARIATION }\end{array}$ \\
\hline Normal................ & & & $\begin{array}{c}m M . \\
\text { Less than } 20\end{array}$ \\
\hline Nephritis, total.............. & 25 & 13 & $46.6-6.1$ \\
\hline Nephritis............... & 6 & 6 & $46.6-30.0$ \\
\hline Nephritis........... & 7 & 7 & $30.0-25.0$ \\
\hline Nephritis................. & 5 & 5 & $25.0-20.0$ \\
\hline Nephritis. . & 7 & 6 & Less than 20 \\
\hline
\end{tabular}

changes similar to those described here. He believed the most important factor causing the acidosis was an increase of undetermined anions. In a few cases low values for sodium were found. Fiegl (12) and later Denis and Hobson (13) made studies of the cations of sera from cases of chronic nephritis which did not show any very marked changes. Two cases of uremia studied by Salvesen and Linder (14) had total base within normal limits.

The variations of these different factors are best shown by a study of individual cases. These also serve to illustrate the great influence 
TABI.E 6

Variation of total base and base combining power of the different acids in individual cases of chronic nephritis*

\begin{tabular}{|c|c|c|c|c|c|c|c|c|c|}
\hline CASE & DATE & $\begin{array}{c}\text { BLOOD } \\
\text { NON- } \\
\text { PROTEIN } \\
\text { NITRO- } \\
\text { GEN }\end{array}$ & $\begin{array}{c}\text { BASE } \\
\text { BOUND } \\
\text { BY } \\
\text { PROTEIN }\end{array}$ & $\begin{array}{c}\text { BASE } \\
\text { BOUND } \\
\text { BY } \\
\text { INOR- } \\
\text { GANIC } \\
\text { P }\end{array}$ & $\mathrm{Cl}$ & $\mathrm{H} \overline{\mathrm{C}} \mathrm{O}_{3}$ & $\begin{array}{l}\text { DETER- } \\
\text { MINED } \\
\text { ACCDS }\end{array}$ & $\begin{array}{l}\text { TOTAL } \\
\text { BASE }\end{array}$ & $\begin{array}{c}\text { UN- } \\
\text { DETER- } \\
\text { MINED } \\
\text { ACIDS }\end{array}$ \\
\hline \multirow{4}{*}{35805} & 1925 & $\begin{array}{l}\text { mg. } \\
\text { per cent }\end{array}$ & $m M$. & $m M$ & $m M$ & $m M$. & $m M$. & $m M$ & $m M$. \\
\hline & January 30 & 170 & 9.5 & 6.2 & 75.6 & 23.0 & 114 & 138 & 24 \\
\hline & February 3 & 210 & 9.8 & 9.1 & 70.6 & 18.7 & 108 & 136 & 28 \\
\hline & $\begin{array}{c}\text { February } 5 \\
1924\end{array}$ & 242 & 7.2 & 9.7 & 67.3 & 16.6 & 101 & 135 & 34 \\
\hline \multirow{3}{*}{34802} & October 9 & 93 & 11.2 & 3.5 & 91.6 & 21.1 & 127 & 138 & 11 \\
\hline & October 14 & 126 & 13.1 & 5.1 & 79.7 & 21.6 & 119 & 142 & 23 \\
\hline & October 22 & 159 & 12.2 & 5.4 & 82.7 & 17.4 & 118 & 145 & 27 \\
\hline \multirow{3}{*}{33049} & April 26 & 234 & 9.8 & 7.2 & 86.9 & 12.8 & 117 & 146 & 30 \\
\hline & April 30 & 272 & 9.9 & 9.0 & 86.9 & 11.8 & 118 & 148 & 30 \\
\hline & 1925 & & & & & & & & \\
\hline 35795 & $\begin{array}{c}\text { January } 30 \\
1924\end{array}$ & 240 & 11.6 & 5.2 & 92.2 & 8.7 & 118 & 146 & 28 \\
\hline \multirow{2}{*}{35344} & December 4 & 215 & 12.6 & 3.8 & 109.6 & 6.0 & 133 & 150 & 17 \\
\hline & December 5 & 223 & 11.6 & 4.2 & 103.8 & 6.3 & 126 & 152 & 26 \\
\hline \multirow{2}{*}{39242} & November 7 & 85 & 11.5 & 3.0 & 109.6 & 19.9 & 144 & 162 & 18 \\
\hline & November 14 & 85 & 11.6 & 3.7 & 109.8 & 18.8 & 144 & 150 & 6 \\
\hline 35558 & $\begin{array}{c}\text { December } 31 \\
1923\end{array}$ & 288 & 11.8 & 5.8 & 111.8 & 3.4 & 133 & 164 & 31 \\
\hline 14118 & December 9 & 198 & & & 127.1 & 13.1 & & & \\
\hline 15071 & $\begin{array}{c}\text { December } 13 \\
1924\end{array}$ & 91 & & & 120.0 & 12.0 & & & \\
\hline \multirow{4}{*}{29796} & April 7 & 134 & 9.3 & 3.7 & 93.8 & 15.0 & 122 & & \\
\hline & April 14 & 164 & 8.5 & 3.4 & 93.4 & 19.7 & 125 & & \\
\hline & April 23 & 190 & 9.5 & 5.2 & 87.2 & 24.3 & 126 & 162 & 36 \\
\hline & April 25 & 194 & 10.1 & 5.8 & 83.5 & 22.3 & 122 & 151 & 29 \\
\hline \multirow{3}{*}{29636} & March 18 & 107 & 11.7 & 4.4 & 107.4 & 13.6 & 137 & & \\
\hline & March 26 & 133 & 11.5 & 5.5 & 96.5 & 15.7 & 129 & & \\
\hline & April 18 & 81 & 12.9 & 3.9 & 88.8 & 26.3 & 132 & 148 & 16 \\
\hline
\end{tabular}

* All determinations were on serum obtained without exposure to air except those on cases nos. 14118 and 15071 where oxalated blood was saturated at $38^{\circ} \mathrm{C}$. with $\mathrm{CO}_{2}$ at 40 $\mathrm{mm}$. tension and the plasma then obtained. 
chloride variations have on the degree of acidosis. A few case studies are shown in table 6. They are discussed in the order in which they occur in the table. As in the previous tables, values are expressed in millimols of base-combining capacity. Blood non-protein nitrogen: is shown in the third column. The base equivalent of the chloride, bicarbonate, phosphate and protein combined is placed in column 8 under the heading, "determined acids." "Undetermined acids," in column 10 is simply the difference between the total base and the determined acids.

The first patient (no. 35808) was a young man, 24 years old, who presented a typical picture of chronic interstitial nephritis. He had been vomiting almost constantly for 3 weeks and at the time of admission was obviously extremely ill. Vomiting continued; he grew progressively worse and died after being in the hospital one week. In the 3 studies which were made the total base of the serum remained constantly low. The total determined acids were low and decreased steadily at the expense of chloride and bicarbonate. In addition to the low base there was a definite and progressive increase in undetermined acids, during the week before death. The relationship of chloride to biçarbonate is worthy of special note. The chloride was extremely low; the reduction probably exaggerated by vomiting. As a result bicarbonate was not nearly as low as it might otherwise have been. In this case we should conclude that the acidosis was caused by both a decrease in total base and an increase in the undetermined acids and phosphate but was masked to a large extent by the extremely low chloride.

The second patient (no. 34802) was a woman, 65 years old, with chronic nephritis who had been vomiting quite frequently for several weeks. The blood examinations were made during the two weeks before death. Vomiting recurred at frequent intervals throughout this period. The changes in the blood electrolytes are similar to those of the first case. The total base was low but increased somewhat. During the same period the total acids decreased. This resulted in a steady increase in the undetermined acids. Increasing acidosis was not associated with increasing phosphate. In this case the acidosis was again mitigated by the low plasma chloride.

The next case (no. 33049) was a woman, 50 years old, with severe 
symptoms who had been vomiting frequently for about 2 weeks. The blood examinations were made 5 days and one day before death. She also had low total base and high undetermined acids. Between the two blood examinations, in spite of the administration of $2000 \mathrm{cc}$. of physiological saline subcutaneously, total base remained practically unchanged.

The next patient (no. 35795) was a young woman, 26 years old with a marked exaggeration of symptoms during the preceding 3 weeks accompanied by frequent vomiting. The findings were similar to those of the last case except for the presence of higher chloride, associated with lower bicarbonate.

In another similar case (no. 35344) the symptoms were of shorter duration and the vomiting less severe. This young woman, 27 years old, had had definite symptoms for only 2 weeks and had only occasionally vomited. The reduction in total base and increase in undetermined acids were less marked than those of the previous case but very low bicarbonate was again associated with high chloride.

- The next case (no. 39242) presumably had marked renal disease of a chronic type with no evidence of severe renal decompensation. She had been practically free from symptoms but showed arteriosclerosis, hypertension, albuminuria and very low phenosulfonephthalein excretion. Here, though the total base and acids were normal there was again a recession of bicarbonate in favor of chloride.

Case 35558 had severe symptoms for only 3 days without vomiting. The findings are in striking contrast with the studies on the first four cases presented. Total base was normal, but phosphate elevated and undetermined acids high. Under these conditions high chloride was associated with extremely low bicarbonate. The course of the disease appeared quite different from that of the preceding cases. He grew rapidly worse; gradually passed into coma and died after being in the hospital 48 hours. It is difficult to avoid the conclusion that vomiting has been the important factor causing the variations of chloride and secondarily, variations in the degree of acidosis.

The next two cases (nos. 14118 and 15071) had extremely high chloride. In both cases bicarbonate was low, the sum of chloride and bicarbonate remaining within normal limits.

The last 2 cases illustrate the changes which followed sodium bicar- 
bonate treatment of acidosis. In the first case (no. 29697) the increasing bicarbonate was associated with a decrease of plasma chloride, the total determined acids changing very little. In the third examination the total base was normal but the undetermined acids high. During the 2 days between the last 2 examinations the patient grew rapidly worse and died 48 hours later. During this period he received no sodium bicarbonate and was not vomiting. Total base, bicarbonate and chloride all decreased and the undetermined acids remained elevated.

The last case presented similar phenomena. Between the first and second blood examination the patient vomited for several days. Within this period there was a marked fall of plasma chloride and a slight increase of bicarbonate. During the 2 weeks preceding the third examination he received 56 grams of sodium bicarbonate. Chloride receded as bicarbonate increased; the reciprocal alterations of the two acids were almost equimolecular. After bicarbonate the total base remained relatively low.

\section{SUMMARY}

It appears that a reduction of total base and an increase of undetermined acids are the most significant factors causing acidosis in chronic interstitial and arteriosclerotic nephritis, phosphate playing a somewhat less important rôle. The degree of acidosis appears to be greatly influenced by variations of plasma chloride. Frequently, especially in the presence of vomiting, chloride may be quite low, thus freeing base to combine with bicarbonate and resulting in only a slight reduction of $\mathrm{CO}_{2}$. With high chloride bicarbonate may be extremely low. These studies emphasize the profound changes which occur in the blood electrolytes in the terminal stages of chronic nephritis.

\section{CASE HISTORIES}

Case 35805. A man 24 years old had good health until 2 months before admission to the hospital but since then blurring of vision, loss of weight, headache, weakness and very frequent attacks of vomiting. Three days before entering the hospital there was a sudden onset of shortness of breath and palpitation followed by swelling of the legs. For 48 hours he had voided no urine. He appeared quite ill with some orthopnea and hyperpnea. He was pale and his face appeared puffy. There was a marked albuminuric retinitis. The lungs were clear. His heart was 
considerably enlarged and rapid. The systolic blood pressure was 226, and diastolic 148. There was slight edema of the ankles. The temperature was continually normal. His urine showed considerable albumin, a few hyaline casts and occasional red blood cells. The first arterial blood study was made the morning after he was admitted. Vomiting ceased for almost 24 hours but soon set in again and persisted with great frequency until just before death. On the second day pericarditis developed. Water and nutrient fluids were to a large extent vomited. He died after being in the hospital one week. Further examinations of the arterial blood were made 3 days and one day before death. Following the second blood examination he was given $1300 \mathrm{cc}$. of saline by hypodermoclysis.

Case 34802. A woman 65 years old had had hypertension with headache and cardiac symptoms for 3 years. Some dimness of vision had been developing and later weakness and pallor. For several weeks before admission to the hospital she had been vomiting every morning. Apparently vomiting had been vomiting had been growing more frequent. She was stuporous and appeared quite uncomfortable. Respirations were deep and rapid. She showed pallor of the skin and mucous membranes and definite albuminuric retinitis. Her heart was moderately enlarged and arteries markedly thickened. The systolic blood pressure was 210 and diastolic 100 . The lungs were clear. The liver was moderately enlarged. Her face appeared puffy but there was no edema anywhere. Temperature was normal until a rise 24 hours before death. She entered the hospital October 8; grew progressively worse and died October 26, 1924 . The first blood study was made on the morning after admission. Vomiting recurred at frequent intervals throughout her course in the hospital. The vomitus contained no free $\mathrm{HCl}$ but on various examinations sodium chloride in concentrations of 2 to 4 grams per litre. Further blood studies were made on the 7 th and 15th days. During the 3 days before death she was comatose with increasing respirations. She received 3 grams of sodium chloride on each of the 2 days preceding the third blood examination.

Case 33049. A woman 50 years old had not been well for several years. About a month before admission she had an acute upper respiratory tract infection and about a week later began to vomit. Vomiting grew progressively worse and she had eaten practically nothing and had taken very little fluids for two weeks. During the two weeks before entering the hospital she had definite cardiac symptoms. Her legs had been swollen for a few days but this disappeared before admission. She was said to have passed no urine for 2 weeks. She was stuporous and had a pasty yellow pallor. The respirations were deep. Her neck veins were distended and she had rales at the bases of both lungs. The heart was slightly enlarged and arteries moderately thickened. The liver was enlarged. The systolic blood pressure was 198; diastolic 110. There was slight edema about the ankles and forearms. The urine showed considerable albumin, a few red blood cells and granular casts. She grew progressively worse and died after being in the 
hospital 6 days. The blood was studied 5 days and one day before death. On the day before the second blood study she received $1000 \mathrm{cc}$. of saline by hypodermoclysis.

Case 35795. A girl 27 years old had always felt below par and for 3 years had complained of headache, weakness and spells of vomiting. Three weeks before admission to the hospital weakness and vomiting increased and dyspnea and pericardial pains developed. She had been vomiting once or twice each day. She looked very old for her age and was emaciated and markedly underdeveloped. She was semi-stuporous, cyanotic and orthopneic. Respirations were deep. There was considerable brownish pigmentation about the face and neck, hypertension, marked arteriosclerosis and evidences of cardiac failure. Slight edema was present about the ankles. After entering the hospital she grew progressively worse, vomiting almost continuously, and died on the 4th day after a convulsion.

Case 35344. A girl 27 years old who had always had rather poor health had an attack similar to the present illness 7 years before. Two weeks before entering the hospital she began to suffer from headache, dizziness, insomnia, urinary frequency and vomiting. These symptoms grew progressively more severe. Dyspnea and palpitation developed. Twenty-four hours before admission she had a convulsion and had been comatose since. Her respirations were regular, rapid and fairly deep. There was marked pallor and puffiness of the face. Her heart and lungs were negative. The systolic blood pressure was 215; diastolic 115 . The arteries were slightly thickened. Her eye-grounds showed no exudate and there was no edema. The urine showed considerable albumin and many casts but no red blood cells. She gradually grew weaker and died 28 hours after being admitted to the hospital. Blood was examined at the time of admission and again 15 hours later.

Case 39242. A woman 30 years old apparently had had marked renal involvement during a pregnancy 9 years ago. Since then she had had no symptoms but her blood pressure remained moderately elevated and a marked albuminuria continued. She entered the hospital for one week for an investigation of her condition. Phenolsulfonephthalein excretion remained below 10 per cent. Two examinations of her blood were made while she was in the hospital.

Case 35558. A man 68 years old who had had very good health all of his life began to suffer from weakness and shortness of breath about a month before admission to the hospital. There were no marked changes in his general condition until 3 days before admission when he suddenly became quite irrational. There had been no vomiting. He was obese, slightly cyanotic and breathing deeply. There was marked arteriosclerosis and hypertension and moderate enlargement of the liver. His urine showed a trace of albumin and occasional red blood cell. He gradually passed into coma and died after being in the hospital 48 hours. Blood was examined shortly after admission. 
Case 14188. An Italian laborer, 49 years old, had complained of headache and stomach trouble for several years. During this time he had had occasional attacks of vomiting, urinary frequency and mild cardiac symptoms but no edema. Symptoms were somewhat exaggerated just before admission to the hospital. On examination he showed chiefly a marked brownish pallor of the skin, a slight increase in the depth of respirations and marked arteriosclerosis. His eye grounds showed no hemorrhages or exudate. The systolic blood pressure was 150, diastolic 100. There was no edema. He grew rapidly worse, muscular twitchings developed and later convulsions and coma. He died after being in the hospital 10 days.

Case 15071. A woman 53 years old had complained chiefly of dyspnea, palpitation and precordial pain on exertion for over 3 years. For almost 3 months she had had weakness, anorexia and a productive cough. Three weeks before admission to the hospital she vomited after meals for several days. This was followed by a typical attack of herpes zoster. There was no marked exaggeration of her symptoms just before entrance to the hospital. She was pale and undernourished and showed marked arteriosclerosis, hypertension and albuminuric retinitis. There was no edema. Her urine showed a low specific gravity, a trace of albumin and occasional hyaline casts. During the first month in the hospital there was definite improvement in her general condition. Then vomiting set in and she grew steadily worse and died after being in the hospital 7 weeks. The blood examination recorded here was made soon after admission.

Case 29796. A man 62 years old had had a stroke 5 years before from which he completely recovered. Seven weeks before admission he began to suffer from shortness of breath on slight exertion and a little later his legs became swollen. Edema gradually became marked, involving even his hands and face. There was no history of vomiting before admission. He was somewhat pale and slightly drowsy. He looked dehydrated although edema involved almost the entire body. There was slight hyperpnea but no orthopnea. His heart was moderately enlarged but not rapid. The lungs showed signs of fluid at the bases. The liver was moderately enlarged. The arteries were definitely thickened. The systolic blood pressure was 210 and the diastolic 110. His eye grounds showed retinal hemorrhages but no exudate. The urine showed a very heavy albumin reaction, low specific gravity and little of importance in the sediment. Phenolsulfonephthalein excretion was less than one per cent. Blood Wassermann reaction $4+$. Throughout his course in the hospital there were recurring attacks of vomiting. Four blood examinations were made. Between the first and second he received 21 grams of sodium bicarbonate, and between the second and the third 25 grams. During the 3 weeks he was in the hospital there was little change in his general condition until just before the last blood examination. Sodium bicarbonate administration and vomiting had stopped. Respiratory distress became extreme and there was evidence of a rapidly failing circulation. He died 
48 hours after the fourth blood examination. Autopsy showed marked arteriosclerosis of the kidneys.

Case 29636. A man 38 years old was admitted to the hospital with a history of long standing hypertension with attacks of cardiac failure. His symptoms just preceding admission were chiefly cardiac. He showed anemia, hypertension, cardiac enlargement and evidence of cardiac failure, without edema. His eye grounds showed hemorrhages and exudate. He failed to improve at first, growing progressively weaker and developing gastric symptoms with nausea and vomiting. These symptoms disappeared after a few days and he began to improve. The first blood examination was made the morning after admission; the second 8 days later. During the $\mathbf{1 6}$ days preceding the third blood examination he received 56 grams of sodium bicarbonate ( 5 grams daily for 4 days and 3 grams daily thereafter). He was discharged definitely improved after being in the hospital one month. The patient died at home about one month later.

\section{BIBLIOGRAPHY}

1. Van Slyke, D. D., and Cullen, G. E.: Jour. Biol. Chem., 1917, xxx, 289. Studies of Acidosis. I. The Bicarbonate Concentration of the Blood Plasma; Its Significance, and Its Determination as a Measure of Acidosis.

2. Austin, J. H., Cullen, G. E., Hastings, A. B., McLean, F. C., Peters, J. P., and Van Slyke, D. D.: Jour. Biol. Chem., 1922, liv, 121. Studies of Gas and Electrolyte Equilibria in Blood. I. Technique for Collection and Analysis of Blood, and for Its Saturation with Gas Mixtures of Known Composition.

Peters, J. P., Bulger, H. A., Eisenman, A. J., and Lee, Carter: Total Acidbase Equilibrium of Plasma in Health and Disease. I. General Method Study and Application to Problems of Physiology. (To appear.)

3. Austin, J. H., and Van Slyke, D. D.: Jour. Biol. Chem., 1920, xli, 345. Determination of Chlorides in Whole Blood.

4. Van Slyke, D. D.: Jour. Biol. Chem., 1923, lviii, 523. The Determination of Chlorides in Blood and Tissues.

5. Vạ Slyke, D. D., and Stadie, W. C.: Jour. Biol. Chem., 1921, xlix, 347. Studies of Acidosis. II. A Method for the Determination of Carbon Dioxide and Carbonates in Solution.

6. Briggs, A. P.: Jour. Biol. Chem., 1922, liii, 13. A Modification of the BellDoisy'Phosphate Method.

7. Benedict, S. R., and Theis, R. C.: Jour. Biol. Chem., 1924, lix, 63. A Modification of the Molybdic Method for the Determination of Inorganic Phosphorus in Serum.

8. Van Slyke, D. D., Wu, Hsien, and McLean, F. C.: Jour. Biol. Chem., 1923, lvi, 765. Studies of Gas and Electrolyte Equilibrium in the Blood. V. Factors Controlling the Electrolyte and Water Distribution in the Blood. 
9. Gram, H. C.: Jour. Biol. Chem., 1923, lvi, 593. Observations on the Regulation of Osmotic Pressure (Conductivity, Chlorides, Freezing Point and Proteins of Serum).

10. Denis, W.: Jour. Biol. Chem., 1921, xlix, 311. Sulfates in Blood.

11. Marrack, John: Biochem. Jour., 1923, xvii, 240. The Balance of Anions and Kations in the Plasma in Nephritis.

12. Fiegl, J.: Zeitsch. physiol. Chem., 1920, cix, 280. Neue Beiträge zur Kenntnis der anorganischen Stoffe des Blutes. I. Kationen und Hyperphosphatämie bei Morbus Brightii.

13. Denis, W., and Hobson, S.: Jour. Biol. Chem., 1923, lv, 183. A Study of the Inorganic Constituents of the Blood in Nephritis.

14. Salvesen, H. A., and Linder, G. C.: Jour. Biol. Chem., 1923, lviii, 617. Observations on the Inorganic Bases and Phosphates in Relation to the Proteins of Blood and Other Body Fluids in Bright's Disease and Heart Failure. 